\title{
Quest to Freedom: Reclaiming Individuality through Sado-Masochism in Faggots by Larry Kramer
}

\author{
Tay Lai Kit \\ Faculty of Modern Languages and Communication, Universiti Putra Malaysia, Malaysia \\ Kamelia Talebian Sedehi \\ Payam Noor of Isfahan, Iran
}

\begin{abstract}
Individuality is the quality or character of a particular person that distinguishes them from others of the same kind. In other words, it is the mark which separates its existence from the rest of the group. According to Fromm, the process of individuality begins at infancy level when the child is separated from the mother. This then takes an emotional toll on the child as he suffers from loneliness and anxiety which stem from the prior separation. The child will henceforth acquire his individuality through the process of socialization which requires constant interaction with people in his life. For this paper, we have selected a novel, Faggots, authored by Larry Kramer, to be the main text for our research. This article argues that the characters in the text are conflicted with feelings of anxiety and loneliness as they embark on respective quest to eradicate the feeling of loneliness by looking for a potential life partner. However, these characters go through a series of promiscuous relationships by living an active sexual lifestyle on the ground that they are in search of the "right" one. Therefore, this paper will look into the sadistic and masochistic (sometimes both; otherwise known as sadomasochistic) tendency practiced by the characters in the novel in their quest to reclaim their lost individuality. This research draws in the concept of freedom, sadism, and masochism as proposed by Erich Fromm to further consolidate the findings.
\end{abstract}

Index Terms-Faggots, freedom, individuality, masochism, sadism, socialization

\section{INTRODUCTION}

In its broadest sense, individuality is the quality or character of a particular person that distinguishes them from others of the same kind. In other words, it is the mark which separates its existence from the rest of the group. According to Fromm, individuation is a process which starts from childhood. Initially, the child believes that he and his mother are one, sharing the same body. However, after a while, he slowly notices that he is a completely separate entity, a brand new being on his own. The child perceives that the outside world and his body are separate and at this point the process of individuation starts. As a result of this process, the child gains maturity in the sense of mentality, physicality and emotion. However, there is a negative effect which derived from this process. As stated by Fromm, the process of individuation leads to the child to a state of loneliness. When the child recognizes that he is separated from others and that he is "different", he becomes aware of being his being "alone". As such, the sense of loneliness renders the child anxious and powerless. In order to overcome this loneliness and its negative feelings, the child attempts to submerge himself with outside world by interacting with other humans.

When the child submits to the process of socialization, he loses the original individuality that he initially had, due to various influences by other individuals. Therefore, one can notice that despite people are constantly in search of freedom throughout history, they ultimately choose to be with someone and remain grounded. This is because when it comes to the process of individuation, they feel alone and thus seeks to escape the freedom which brings them the negative feeling of loneliness. As Fromm mentions

The battles for freedom were fought by the oppressed, those who wanted new liberties, against those who had privileges to defend. While a class was against those who had privileges to defend. While a class was fighting for its own liberation from domination, it believes itself to be fighting for human freedom as such and thus was able to appeal to an ideal, to the longing for freedom rooted in all who are oppressed. (1942, p. 1)

As far as history can date, humans from across the world have constantly strived to attain freedom; be it personally, sexually, or even on a bigger scale, such as nation-level. On a global scale, battles are fought and blood shed - all for the purpose of gaining freedom. However, on a smaller scale, in which this case refers to individuals, they seek to renounce their "freedom", which according to Fromm, essentially means the state of being by oneself. This freedom usually leads the child to state of loneliness, whereby he will look for alternatives to eradicate the feeling through social interaction. "The individual was left alone; everything depended on his own effort" (Kariel, 1957, p. 645). Knight emphasizes that all sorts of responsibilities and problems that each individual faces alone leads to a feeling of 
inadequacy, confusion, and helplessness (1942, p. 299). As a result from bearing the burden alone, it would be easier for the child to shape and mold himself to a person or character which belongs in the society. The social bonds fostered through interaction form ties which, in return will bind them from his prior quest, which is to regain his individuality. By submitting themselves, not only do they lose their individuality but also freedom. The submerging and forced attachment with other individuals can happen in various ways, and this paper will focus on the concepts sadism and masochism.

In general, sadism refers to the tendency to derive pleasure, especially sexual gratification, from inflicting pain, suffering, or humiliation on others. Sadists intend to let people to be dependent on them which, in return, gives them the power over them. In this sense, sadists might exploit, use or manipulate the other person, which sometimes leads the person to physical or mental suffering. They hurt, humiliate and embarrass the other person with their maniac treatment. By possessing power and control, a sadist feels powerful as he gains satisfaction and gratification from his devious act. As Fromm notes, "the sadist needs the person over whom he rules, he needs him very badly, since his own feeling of strength is rooted in the fact that he is the master over someone" (1942, p. 125). This then leads to the subject on the other side of the situation - who would willingly submit themselves to such torturous and humiliating act inflicted upon them?

As probed earlier in the previous line, it is the masochist who enjoys being subjected to acts of torture. Masochism generally refers to the tendency of deriving sexual gratification from one's own pain or humiliation .He sometimes inflicts pain on himself to gain the attention of others. Fromm asserts that "there are people who indulge in selfaccusation and self-criticism which even their worst enemies would scarcely being against them" (p. 123). Tay and Sedehi mention that "masochism indicates the deviant behavior or psychological illness whereby one takes pleasure in suffering" (2016, p. 242). Hence, this paper intends to focus on the concepts of sadism and masochism by Eric Fromm and apply them to Larry Krammer's Faggots. Findings will illustrate how characters deal with one another in their quest to regain their individuality by getting involved in promiscuous relationships, which the paper argues for its sadistic and masochistic elements.

\section{ConcePtual Framework AND Methodology}

For the purpose of this study, the researchers employed a novel written by Larry Kramer entitled Faggots (1978). Further, the paper utilizes the concepts of sadism and masochism as proposed by Erich Fromm in his book, Fear of Freedom (1942), focusing on various homosexual characters in the novel in regards to their quest of regaining their individuality which they lost after the separation from their mothers. It is important to note that the relationship between a sadist and a masochist in most cases is referred to as master-slave.

Richard Von Krafft-Ebing developed the neologisms sadism and masochism, stated in 1890 that "masochism and sadism appear as the fundamental forms of psycho-sexual perversion, which may make their appearance at any point in the domain of sexual aberration" (1965, p. 217-218). According to Fromm, humans are social beings who need to be in contact with others. They do not want to be alone because individuality scares the characters; "when one has become an individual, one stands alone and faces the world in all its perilous and overpowering aspects" (Fromm, 1942, p. 24). As a result, the characters indulge themselves in a series of promiscuous relationships solely because they cannot stand the price of freedom which is the feeling of loneliness. As such, their decisions are seen as acts of sadism and masochism due to the violent nature of their relationships. It is imperative to note that one character can sometimes inhibit both tendencies and is addressed as sadomasochism. In this case, the character takes pleasure in either inflicting pain on someone else, or being the subject of torture himself. But for those who are distinctly either one or another, they develop a codependent relationship with one another because both parties need each other for the fulfillment of their twisted desire. Consequently, both the sadist and masochist lose their individuality as they submit themselves to the will of the other party. This attempt to reclaim their lost individuality proves to be ironic as it contradicts the initial motive which is to find a steady and loving relationship.

The novel is written in a fragmented manner which stylistically highlights the distorted reality for the characters in the novel. The overall plot includes a highly complicated and complex string of relationships between all characters in one way or another but one thing they share in common is that they constantly bound to a chain of miserable lifestyle due to poor decisions. This justifies the reason as to why this paper contains only several characters as the main focus for the analysis. On that note, there is one particular character who stand out above rest, which the researchers deem to be the protagonist, Fred Lemish, who also seeks his lost individuality in the story. All in all, the current article focuses on the how the characters: 1) regain their individuality by attaching themselves to people through sadomasochistic tendency; and 2) realizes that the only way they could reclaim their individuality is through self-love.

\section{ANALYSIS}

The novel starts with various characters who are in promiscuous relationships. They are looking for potential relationships everywhere as their main concern is to find love. During this process, they gradually turn into characters who practice masochism and sadism, in which it becomes a habit and then a lifestyle later on. The sexual slave should keep silence and be obedient whenever the master asks him to. "Yet here Fred was, viewing the Slave on the bed. He 
wondered, too, what it was like to be a Slave. The Slave remained prone and silent, up- ended, as any good slave must obviously remain" (Kramer, 2000, p. 6). Whatever the master suggests, the slave does and acts upon it without question and hesitation. Palazzolo mentions that "the desire to dominate the will of other people can be viewed as a depravity of a genuine sense of potency borne out of helplessness, powerlessness and inferiority" (2007, p. 154). This notion highly resonates with Freud's idea of projection whereby the perpetrator is projecting his own insecurity unto the partner as an outlet and coping mechanism to his own flaws. To be specific, Freud parallels masochism as a destructive dynamic that inclines towards self-destruction (ibid. 170).

At the beginning, the protagonist Fred Lemish is seen to be experimenting with his sexuality and loneliness by cruising around night clubs where people are conducting perverse sexual actions. He is simultaneously revolted and excited by the scene because of his curiosity and fear. He isolates himself from the action but continues to observe other people. He thinks that he can overcome the loneliness by mere observation but sinks into depression gradually throughout the story. This reflects his masochistic tendency in his attempt to overcome his loneliness because he suffers by not participating in the social process. As Fromm puts it:

Alienation, however, does not lead our hero out of society, but deeper into it, for he is impelled by a curiosity to known, down to the smallest detail, the corrupt world that he wishes to escape. Concealing his opposition, he takes part in the intrigue of his day with the secret aim of proving to himself, by the very falseness of his conduct, the distance that separates him from his contemporaries. (1942, p. 9)

The excerpt above stresses on the ironic effect of alienation in a sense that the curiosity of a person will eventually triumph over the physical isolation because one will always look for alternatives to be in the social circle. It sums up Fred's life as well as his decision to remain detached. He proves to be masochistic as he imposed loneliness onto himself.

For these characters, sexual intercourse is just a way for them to be together as they are scared to be alone. Even though the relationship is that of sadomasochistic nature, they do not seem to mind it because they are temporarily content with having someone to be intimate with. "I haven't sucked you out yet!" the Master/Pisser pleaded. Fred ran out of the cubicle, not listening as the Master apologized to Slave: 'it's all right, honey, I'll find you another time"' (Kramer, 2000, p. 12). They satisfy their needs and complexities by becoming as sadists and masochists. On one hand, being punished can be sexually gratifying while the other one enjoys dominating the other person. Loneliness is a constant struggle for these characters because it highlights the detachment and sorrow of the process of individuation. Therefore, the instant solution which they settle on is meaningless hookups which ultimately results in failure and disappointment. "I repeat: what love? Are you not confusing sex and love?" (Kramer, 2000, p. 29). There is no sense of love or any form of emotional bond between the characters at all. In this sense, physical intimacy is seen as an immediate release for them which highlights the severe sadomasochistic tendency in them. They deal with the inner loneliness by having promiscuous relationships which eventually grow into self-hatred. For instance, Fred says "[b]ut when I look around me, all I see is fucking, all we do is fuck. With dildos and gallows and in the bushes and on the streets" (Kramer, 2000, p. 31). Promiscuity is rampant among these gay characters as they are in search of love in various relationships, but they cannot find it anywhere.

Richard is another masochistic character which is introduced in the novel. He kidnapped himself as he needed attention from others. By inflicting pain on himself, he attracts the attention. "His own self-inflicted kidnapping" indicates how far the masochists can go when they need attention (Kramer, 2000, p. 22). Moreover, he hated his mother because of the way she treated him, but still he played the news of him being kidnapped in which the mother reports to police. He "knew he would cry when he saw his mother on the news", but still he watches it as he is a masochist and finds pleasure in torturing himself (Kramer, 2000, p. 22).

On the contrary to masochists who accept other people's order, and enjoy being tortured and enjoy the suffering, some people are sadists. They enjoy ordering others and impose suffering on them. In this novel, Fred is a sadomasochist character. Based on Fromm, "sadomasochistic love is born out of the inability to stand alone and bear solitude" (Palazzolo, 2007, p. 144). The fear of being alone, lead these characters to perverted kind of love. The true love will not hurt the other person; however, in their cases, they take pleasure by imposing pain on others. For instance, in some cases Fred shows his sadist side and in others in indicates his masochist side. When he is a sadist he thinks that he has ownership of other characters. "Fred was glorifying in the knowledge of true ownership: this Perfection is Mine! I love it!" (Kramer, 2000, p. 20). He claims that he loves those who are in relationship with him, but at the same time, he considered himself as the master. He owns those humans like a master owns a slave.

The characters are aware of their dependence on each other; however, when they have the freedom to choose, they are so petrified that it stifles them. One of the characters in the novel who is also in search of his subjectivity is Abe. "He does not know it, but the horrors he is to confront in this latest chapter of his search for Meaning, Enlightenment, Where Is the Rational?, on which the emancipated Jew so prides himself, will be such as to make him... what? A Job? A Hitler? An Abe?" (Kramer, 2000, p. 41). As indicated, his lack of self-identification in terms of his prospect in life has made him an unsure individual. He does not have a stable stance on who he is as a Jew and therefore, hulls himself into the world of promiscuous relationships whereby he sticks to the ways of the other person. In return, he gets superficial assurance of his life for once and does not have to trouble himself by the overbearing thoughts. 
Similarly to Abe, Fred too, goes through a series of uncertainty in his life as an adult man. While he is described as a perfectly good looking and functional man with good physique, he struggles with his own subjectivity as well. Although he is single and looking, he cannot seem to engage himself in the social interaction with other characters. In fact, he is horrified with the world and how it has reached to such decadence in morality; thus, he is scared of exploring new things. His freedom in being an individual proves to be too extreme for him; listing out the many fears he suffers from.

1: Algonqua smothered me to death with her "Love"; 2: Lester hated me; 3: I want to be Hurt; 4: I don't want to be Hurt; 5: I want to Hurt somebody else; 6; I seek the tensions of my shitty childhood; 7: I seek as lovers only those who embody the identical responses that Algonqua and Lester, those cocked- up fronts from whence all patterns flow, programmed into me; 8: I refuse to compete in anyway with ultra- straight brother Ben; 9: I'm still trying to be accepted as "one of the boys" I never was in youth, 10: I have a bad relationship with my body and need constant re-affirmation by a bevy of parading beauties that I Am Hot... (Kramer, 2000, p. 105)

Fred lists down all the reasons in order not to search for his individuality as freedom of choice is threatening. Palazzolo states that "[i]t is a fleeing from aloneness that generates the desire to submerge the self with others and/ or with the things of the world so that we can be relieved from the unbearability of anxiety and panic that is set off by each person's sense of isolation (2007, p. 149). The characters in the novels have an intense codependency with each other because of their respective fear of being alone. Their quest in reclaiming individuality is juxtaposed with a negative lifestyle filled with social vices. As mentioned before, Fred is a masochist who takes pleasure in rejection of others and by living in denial. This is highlighted in a scene where he does not have the courage to be firm with his "boyfriend" on fixing a date night. He is constantly rejected and rescheduled, to a point where the two scarcely meet, and yet he remains stagnant where he is, content with the situation. In fact, Fred is so accustomed to this habit that he has experienced the same thing with other men previously in his life;

Recalling a night in London when a handsome French man he'd picked up in Piccadily Circus had threatened him with knives, recalling how First Love Feffer had one mysterious evening in New Orleans tried to tie him up and whip him with a belt, recalling how Feffer ever thereafter claimed Fred to be a true masochist, sending vibrations out to all the world's true sadists that he was just begging to be punished- all of these nocturnal emissions prompted Fred to immediately jump into his clothes, leave this one at the tubs. (Kramer, 2000, p. 170)

Accordingly, Fromm notes that the masochists enjoy making themselves insignificant and being belittled (1942, p. 133). The sadomasochists are extremely dependent on each other solely because of the perverted nature of their sense of self and relationship. Fred

found a thick membership directory to Inter-Chain, a world- wide organization of leather and slavery and bondage and Master- Slave with its information under Adams, D., that he was he was interested only in supervising bondage and light whipping and punishment and Master-only rites, together with twenty further copies of that photograph, his Dinky standing tall, cold, immobile, the whipping Master just waiting to be summoned to command, all in those leather items. (Kramer, 2000, p. 191)

The society is a complex mechanism, complicated with various social, political, and economic factor but one thing which persists through all societies is that - it functions on a binary plane. For as long as there is men, there will be women. For as long as there is masculinity, there will be femininity. For as long as there is wealth, there is poverty. The same applies to the twisted relationships of these gay characters in the novel - for as long as there are people who enjoy torturing, there will be people who takes pleasure in being the subject of torture. That then solidifies the codependency amongst the characters but thus, losing their individuality which they so seek for at the very beginning of the process of individuation.

Masochism can be broken down to few levels depending on the extremity of the action. Some of the more intense masochists enjoy being sexually inferior and punished physically. Paulie enjoys being punished and Timothy is gratified sexually by being harsh to Paulie as Timothy is sadist. As mentioned before, the sadist and masochist satisfy each other's needs and at the same time they lose their individuality. "Paulie said: 'I want you to punish me harder hardest hardingest!' to which young Timothy replied: 'this is the most wicked awfulest most punishing pole stick I ever seen I am going to punish you so good you will never forget it'” (Kramer, 2000, p. 232). They both enjoy punishing and being punished as their mentality works this way. Power, according to Krafft-Ebing, is one of the central defining factors of sadomasochism, more fundamental to than the pleasure-pain complex usually assigned to sadomasochistic erotics (Davis, 2012, p. 50).

Eventually, the characters realize that their constant living in denial and seeking for temporary affection prove to do more harm than good. Their codependency amongst each other has changed them into someone that they are not. Their willingness to change in the process is forged by the sense of isolation and loneliness that they felt when they were alone. As such, they rather mold their characters according to the desire of their respective partners, betraying their true self.

I've been looking, seeking, demanding, the love of Lester all my life. As if... as if... as if a dinky Lester's love would make me whole and everything all right. As if wrestling Lester's love from Dinky's stone would make everything all right. Lester would have loved me. I chose another Lester and tried to make him love me. So I could be lovable. (Kramer, 2000, p. 358) 
Originally, the characters set out on a quest to find themselves, going through the process of individuation because of their fear of freedom. The solitary freedom which they had from being alone proves to be overwhelming and thus, seeking partners to fill that gap. However, it is observed repeatedly in the novel that the characters find themselves being involved in wrong relationships and ultimately ends up having a sense of loathsome and depreciation for their dignity. They do it nonetheless because of the destitution faced when being alone. Therefore, their situation can be equaled to that of a double-edged sword, for the result of their attempt is just as malicious as compared to when they were lonely. On one hand, the characters lost their individuality from the separation at birth, and on the other; they suffer loss of identity. Despite everything, they managed to come to their senses concerning their situation. They emphasize the fact that all this while they played the roles to fit in with everybody else and not being true to themselves.

At this point tears turn to anger. Anger finally arrives. How dare we have treated ourselves and each other so badly? Anger. For love unrealized. For settling for so little. For humiliation and its pleasure. For foolishness revealed. For having loved half a person. And therefore having hoped only half fully. For being putty. For cowardice and being Lester's sissy. For selfishness. For playing the petty game of dangler and dangle. For life still undefined. For lies. To self and others. For the lack of courage to be faithful. To self and love. You and Me, Dinky. We've been both the same. I fell in love with a role player, not a role model, and I've been just the same. It was my fault. (Kramer, 2000, p. 359)

They acted all this while and they did not show their true nature as they were scared their true self might scare the other person away. At this point of time, the characters sense of individuation which is "the process by which an individual emerges" (McLaughlin, 1996, p. 245). They were oblivious to the fact that being ignorant to themselves leads to self-hatred. The newfound awareness brings about another perspective of appreciation and fresh start. With much hope and conviction, they finally come to terms with their personal individuality by acknowledging their sense of worth, dignity, and self-love.

\section{CONCLUSION}

To recapitulate, a child starts to undergo the process of individuation upon his realization that he is separated from his mother and that he is his own being. That is when the feeling of loneliness comes in due to the loss of attachment with his mother figure previously. As such, in order for the child to overcome the feeling of loneliness, he goes out attempting to look for similar bond which will secure his feeling again as a person - whole, as though his individuality is attained and in perfect harmony as before. In this paper, the characters go through a series of rough and unpredictable relationships; all of which possesses hints of sadism and masochism. The grotesque nature of those relationships do not seem to faze the characters as they face it boldly, claiming that it is part and parcel of "life" that they have to endure in order to regain their individuality again. However, it is observed repeatedly in the case of the characters in this paper that their quest not only proves to be futile but contradictory to the aim of their quest of identity. As the findings show, the characters ultimately learn to accept themselves as a lone being and that it is only through self-love that they get to slowly and gradually regain what was lost in the first place - their individuality.

\section{REFERENCES}

[1] Davis, Mary Ann. (2012). "Useful Dangers: The Erotics of Forms, Sadomasochism, Victorian Narratives." Diss. U of Southern California, 2012. ProQuest,: 1-246. Print.

[2] Freud, Sigmund. (1995). The Standard Edition of the Complete Psychological Works of Sigmund Freud. 24 vols. Ed. by James Strachey, Anna Freud, Alix Strachey, Alan Tyson, and Angela Richards. London: Hogarth Press and the Institute of Psychoanalysis, 1995.

[3] Fromm, E. (1942). Fear of freedom. London: Routledge.

[4] Kariel, H. S. (1957). The Normative Pattern of Erich Fromm's Escape from Freedom. The Journal of Politics 19 (4): $640-654$.

[5] Knight, F. H. (1942). Review: Escape from Freedom. by Erich Fromm. American Journal of Sociology 48 (2): 299.

[6] Krafft-Ebing, Richard von. (1965). Psychopathia Sexualis: A Medico-Forensic Study, Ernest van den Haag, intro. Harry D. Wedeck, trans. (New York: G. P. Putnam's Sons, 217-8.

[7] Kramer, L. (2000). Faggots. New York: Grove Press.

[8] McLaughlin, N. (1996). Nazism, Nationalism, and the Sociology of Emotions: Escape from Freedom Revisited. Sociological Theory 14 (3): 241- 261.

[9] Palazzolo, S. A. (2007). Demystifying Sexual Perversion: An Existential Reading of Sadomasochism and Erich Fromm's Call to Love. PhD Thesis. Pennsylvania: Duquesne University.

[10] Tay, L. K., Sedehi, K. T. (2016). Normalizing Masochism: Subversion and Reification of Hegemony in Larry Karemer's The Normal Heart. Journal of Language and Communication, 3(2): 241- 248. 


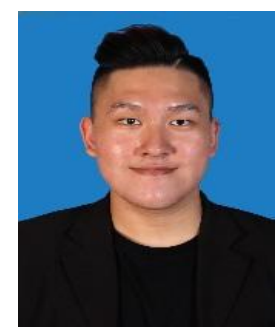

Tay Lai Kit is currently pursuing his Master's degree in English Literature in the Department of English, Faculty of Modern Languages and Communication, Universiti Putra Malaysia. A summa cum laude graduate in similar institution for Bachelor's degree, his field of interest includes gender studies and psychoanalytic cogitation. His ardent spirit and undying passion in the performing arts scene has crafted him into an individual who thrives in an environment of infinite creative possibilities. Due to personal affiliation, he is interested in literary works which deals directly with gender queer experience and psychosocial cogitation.

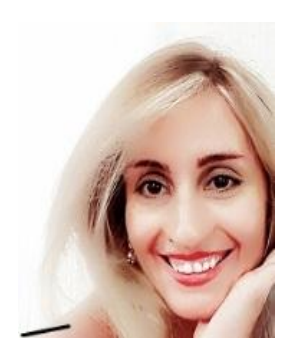

Kamelia Talebian Sedehi is $\mathrm{PhD}$ of English Literature. She received her doctorate from Universiti Putra Malaysia in 2016. She received her B.A. (2009) and M.A. (2011) in English Literature from University of Isfahan. Her research interests are melancholia, trauma, sexuality, gender studies and interdisciplinary topics. She has presented at various national and international conferences and is an experienced university lecturer and teacher. Currently, she is working at Payam Noor University (Isfahan branch), Iran. 